\title{
A Study of Material Management Policies in Chain of Hotel Industry (A Case Study of Taj Hotel)
}

\author{
Apoorva Singh ${ }^{\mathrm{a}}$, Arvind Kumar Yadav ${ }^{\mathrm{b}}$ \\ a, baculty of Commerce, K.M.G.G. (P.G.) College, Gautam Budh Nagar, (U.P.), India \\ Email Id: arvind3510@gmail.com
}

\begin{abstract}
The material management concept advocates integrating all major activities, which contribute material cost to a single department. In this concept the material management department is responsible for purchasing, inventory control, stores and other related activities. Many times in corporate activity, there is compartmentalization of basic management functions concerned with materials. The purchasing department operates separately and other areas like stores and inventory control operate independently. This creates conflicting objectives from the overall organizational point of view e.g. purchasing department may prefer to buy large quantities on discount without considering the warehousing and carrying costs. In an integrated setup, the material manger is responsible for all the interrelated purchases and hence this leads to co-ordination among all activities the total concept of materials management is a major step forward in the management field. Its integrative approach is much more effective as compared to unlinked control practiced earlier. The management of various types of inventories is also a very important task of every organization either it is a manufacturing organization or a service organization including the hospitality industry. In this research paper we focused on different material management policies and purchase plans specially in Taj Hotel.
\end{abstract}

Keywords: Material Management Policies, Hotel Industry, Purchase Plans, Taj Hotel.

\section{PAPER/ARTIClE INFO} RECEIVED ON: 01/08/2019 ACCEPTED ON: 10/12/2019

Reference to this paper should be made as follows:

Apoorva Singh, Arvind Kumar Yadav (2019), “A Study of Material Management Policies in Chain of Hotel Industry (A Case Study of Taj Hotel)", Int. J. of Trade and CommerceIIARTC, Vol. 8, No. 2, pp. 373-386 
A Study of Material Management Policies in Chain of Hotel Industry (A Case Study of Taj Hotel)

Apoorva Singh, Arvind Kumar Yadav

\section{INTRODUCTION}

Polices are statements or decisions made and communicated by the top management of an organization, which applies to a set of circumstances and they can be applied repetitively. They serve as guidelines, which can be used consistently in taking decisions throughout the organization for matters that are repetitive in nature. They should be consistent and clear so that scope of misinterpretation is minimized. Policies are sort of decisions taken in advance for repetitive situations, hence polices should be capable of being implemented without further reference to higher management. They are kind of standing decisions in various areas of operations. Material Management Policies enable to top management to take considered decisions regarding basic questions of continuing importance that confront the various functions. The primary goal of materials management is to obtain materials at lowest price along with consideration of consistency in quality and supply. Another Goal is to maintain a minimum inventory of materials so that minimum working capital is blocked in inventory.

A.K. Dutta defines material management as: "Materials Management can be said to be that process of management which coordinates, supervises and executes the tasks associated with the flow of materials to, though, and out of an organization in an integrated fashion". The objective here is to ensure availability of raw material without adversely affecting the smooth flow of production. At the same time, quality of raw materials must be consistent and above all minimum funds should be blocked in all sorts of inventories. The task of material management is not only important but is a complex one. It requires integration of various departments where inventories are used, produced or kept. This is why usually it is advantageous to have integrated materials management systems. In fact, many times the term 'purchasing department' is quite misleading. This term does not reveal precisely the responsibilities handled by the 'Purchase Department'. There are in many cases involved in activities beyond purchasing like inventory control, audition invoices, stores, receiving etc.

\section{OBJeCTIVES OF THE STUDY}

- To study the meaning of material management policies in various levels,

- To study Integrated material management system and its functions,

- To evaluate material management policies in Hotel Industry

- To study and evaluate the material management policy in Taj Hotel.

\section{Research Methodology}

This research paper is mostly based on secondary data. For Secondary data we have taken relating Material Policies from various books, journals and internet. Government reports and various magazines, newspaper reports have also helped us in this research paper.

\section{INTEGRATED MATERIAL MANAGEMENT}

The term 'integrated material management' refers to the management of resources in an integrative manner to make way for national economic development, through efficient utilization of MIS, innovative, advanced technologies and economic materials for manufacturing. The management needs to develop a comprehensive materials management system to establish a pathway for the most effective use of the resources through new technological advancements, methods and concepts. The major resources are the manpower, materials and money, and hence, 
the critical importance of materials management. Out of these three resources, materials should be managed through proper integration to achieve the following functions:

- Decide on the purchase of materials

- Ensure the centralization of power

- Coordinate all functions of the departments

- Ensure quick and accurate decision-making

- Administer data analysis by Electronic Data Processing (EDP) and use of computing technology

Emphasize on the opportunity for growth

\section{AdVANTAGES OF INTEGRATED MATERIAls MANAGEMENT CONCEPT}

In general, organization, which have an integrated material management system, enjoy the following advantages:

5.1 Improved Accountability: Due to centralization of authority and responsibility for the materials function, clear cut accountability is established and user departments can convey problems, changes required etc. concerning materials to one centralized point so that chances of delay in action are reduced. Also, the performance of material management can be evaluated more objectively.

5.2 Improved Co-Ordination: When the functions of purchase store, inventory control are controlled by one central material manger, these sections create a common identity and there is more co-ordination and co-operation and co-operation to achieve goals of the material function. It also develops trust and better relation with the user departments since they have to approach one department for problems related to materials.

5.3 Better Overall Performance: Communication is speedy due to the integration of the interrelated function of materials. Need for materials by user departments are sent to the stores section. The stores and inventory control section check out stock level \& order status and further pass information to the purchase section.

5.4 Adaptability to Electronic Data Processing: For an integrated setup, it is easier to setup advanced and efficient EDP systems. All information concerning the material management is centralized, so it helps in selection and analysis of data.

5.5 Procurement at The Right Time: The main aim of materials management is to get raw materials and other supplies at the right time. This requires sending of shortage report by the store and ordering by the purchase section, clearing of goods by docks, railways or road transport, checking and receiving materials by the stores. So it is a whole lot of activities, which are involved and the combined setup brings about grater co-ordination and sense to responsibility to procure goods at the right time. Separate functioning of these sections may lead to each blaming the order for delay is procurements.

5.6 Lead Time and Stock Levels: Lead-time may tend to differ with time due to changing condition. This may necessitate adjusting the maximum-minimum levels on stock control cards/software. A common department head rather than a separate purchase officer may effectively tackle this kind of fluctuations.

5.7 Cost Reduction and Productivity: Material Management also aims to increase the productivity of materials, which can be bidding, negotiations and also by value analysis, 
A Study of Material Management Policies in Chain of Hotel Industry (A Case Study of Taj Hotel)

Apoorva Singh, Arvind Kumar Yadav

standardization, bulk ordering, reducing investments and carrying cost by optimum level of inventory, avoiding wastage, obsolescence, etc.

All these things are difficult to coordinate and some of them pull in opposite direction e.g. benefits of bulk ordering and maintaining a low inventory. A common departmental head will take these decisions more efficiently.

5.8 Price and Quantity: The price depends on the quantity brought. If the decisions regarding quantity rests with another department, it work as a impediment. In a combined department the departmental head can negotiate the price on the basis of all factors considered together.

5.9 Unutilized Materials: It is easier for a common department head to sport surplus material and dispose it accordingly.

5.10 Handling Receipts: Handling receipts smoothened when the stores and purchase sections are common e.g. if they are separate; a case of stores getting unloading advice at the last moment may create problems.

5.11 Ensuring Receipt of Right Materials: Combined department ensures in a way that correct material is being received as had been ordered by department.

5.12 Return of Rejections: The combined setup understands the necessity of return and replacement and takes comparatively quick action.

5.13 Reduced Correspondence: Try to less correspondence among various sections due to combined setup.

5.14 Optimum Inventory Turnover: Inventory turnover rate is obtained by dividing the annual sales by the average monthly stock. This indicates the speed at which the materials come in and go out of stores. Ideally, the inventory turnover should be high which means there is rapid movement of materials. This turnover rate can be better manipulated in the integrated department.

\section{MATERIAL MANAGEMENT ACTIVITIES IN THE INDIAN HOSPITALITY INDUSTRY}

A number of similar material management activities are performed in hospitability operation regardless of their size. The major material management activities performed are:

(a) Locating vendors

(b) Deciding a quality

(c) Determining purchase specification

(d) Determining re-order point

(e) Managing inventory levels

(f) Negotiating financial deals

(g) Storage arrangements

(h) Supervising deliver

Large operations concentrate their activities mostly on:

(a) Formulating specifications

(b) Identifying and approving buying source

(c) Evaluating and negotiating with suppliers

(d) Deciding brands to by and revaluating periodically

(e) Periodic approval of new products and substitution of approved items

(f) Invoice approval and payments

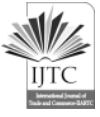


(g) Order placements

Materials Management Activities In Food Service Operations: There are several activities which food service operations perform. The number of activities and procedures vary with the size and nature of the establishments. In small establishments the activities are undertake informally and few people are involved in the process. In large organizations the activities are numerous and more organized.

For better understanding we can divided the activities of Material Management in food service operations into the following three categories: -

a) Pre-purchase Activities: Pre-purchase activities are those, which have to be performed before the actual process of purchasing can begin. Planning of menus is to be done beforehand since unless the menu is planned, it cannot be decided as to what item are to be purchased and in what quantities. Product specifications have to be formulated in consolation with the user department. Appropriate inventory levels are to be determined and order sizes for various types of items have to be considered. Ordering documents also have to be prepared in advance.

b) Formal Purchasing: After pre-purchase activities have been accomplished the formal purchase process can commence. This process comprises of contracting vendors through various means, establishing formal competitive bid process, inviting competitive bids from prospective vendors, evaluating bids on the basis for price, quality \& other factors and warding supply contract to be selected vendors. After the award of supply contract, the vendors supply the items as per pre-decided schedule and the establishment has to arrange to receive items, store them and further issue products to the user departments. Contract performance has to be monitored and evaluated for follow-up action.

c) Informal Purchasing: In case of small sized food service operations, comparatively informal purchasing process is followed and the activities involved are contacting vendors, obtaining price quotes, selecting vendors, placing orders, receiving shipments and issuing products to the user departments.

\section{Purchasing Plan}

The owner in small operations determines the policies and procedures of purchasing and the higher management in larger operations determines them. The policies describe the way as to how goods and services will be selected and procured. This plan can be revised periodically to update it according to the changing trends.

7.1 Need of Products and Services: Need of requirement like quantity of products and services need by the establishment have to be estimated by the buyer. These demands may come from various departments periodically. The buyer along with the end users may together decide on the varieties and amount of products \& services needed.

7.2 Identifying Suppliers: Large Food Service Operation especially chain operation enjoys immense power due to their scale of operations. Chain Food Service operations like McDonalds identified and developed suppliers in India to supply its operations products with specific quality years before launching their first restaurant.

The identification and selection of dependable suppliers who will provide products with consistent quality is very important. For small food service operations, this is a difficult task but 
A Study of Material Management Policies in Chain of Hotel Industry (A Case Study of Taj Hotel)

Apoorva Singh, Arvind Kumar Yadav

for big operations, which generate large volumes, the suppliers would accommodate with the operation's requirements.

In today's competitive world for most products \& services many suppliers will be available. But for some products that are unique in nature or need to be purchased in bulk, the food service operation establishes a supplier. This kind of set-up is referred to as a kind of 'sourcing'. This arrangement benefits both the food service operation and the supplier. The buyer gets a reliable source and the supplier enjoys a predictable volume of business.

As an example, if we the suppliers of McDonalds, we find that chicken and vegetable products are supplied by Vista processed Food. This supplier has world-class infrastructure at their Taloja plant in Maharashtra. Supplier for cheese like Dynamix which have full automated international standard facility to convert milk into cheese, butter/ ghee, skimmed milk powder, lactose, casein, whey protein etc.

7.3 Maintain Optimum Level Of Inventory: A food service operation should strive to maintain an optimum level of inventory. Having higher level of inventory means blocking capital unnecessarily, maintaining extra storage space and it leads to problems like pilferage, over-use and expiry of products. Lower level of inventory means that the operation may run out of items needed (stock out) and this may lead to guest dissatisfaction.

Hence, it is important to maintain sufficient quantity of each item by determining the correct order size of each item and ordering at the correct time.

7.4 Negotiate Deals: Negotiations are an important part of purchasing. Negotiations are needed to settle as purchased (AP) prices, qualitative delivery schedules, packaging details etc. The attitude for bargaining should be fair and not pressing on the supplier for undue price reductions or this may lead the supplier to cut corners in quality. Negotiating power is directly related to the volume of orders.

Negotiating requires time and energy on part of the buyer but the benefits can be immense in terms of quality, price and other conditions.

\section{RESEARCH TO IMPROVE FURTHER OPERATION}

Purchasing is not a static activity and research is needed to improve future operations. Though the basic principle and procedures remain the same, product availability and customer tastes keep changing rapidly in today's globalized world. Supplier services and prices also are not fixed. These areas need to be studied for enabling decisions:

(a) Analysis of Value of Product that are being used can be done i.e. whether certain unnecessary costs can be eliminated without compromising with the quality of the endproduct. The changes, if any should be made in consultation with the user of the product, otherwise such cost saving measures may backfire and create unnecessary problems.

(b) Procreating may be done to identify that trend in product service variety and prices. Commodity pricing can be tracked on line too.

Buyers analyses the effect of price increase of particular commodities on the overall food cost. Mathematical models are used to test various 'what- if problems.

Besides this, demand forecasting is also essential for any industry. Forecasting helps a firm to assess the probable demand and this is an important aid in effective and efficient planning. This is all the more important in food services since the ordering, production and delivery go 
simultaneously unlike in other industries. If the operation does not by enough, it may lead to a stock-out situation and the customers will no be able to buy the desired dish. Over purchasing also poses an equally challenging situation. It will lead to blocking of capital pilferage, over-use, use of old stock and wastage.

It should be emphasized that there is no easy method to predate the future with certainty. Many statistical techniques are used for forecasting. In case of the food service industry forecasting on the basis of analysis of past performance may be most accurate, though other factors should be taken into consideration. The basic assumption of the trend method is that the past rate of demand under study will continue in the future. This technique gives good results as long as there is persistent tendency to move in some direction. But in case of a turning point, the trend projection breaks down e.g. in case of fierce competition from food outlets the analysis of past performance what was sold? When? How much? Etc. many not hold true of future. Prediction does help most of the times and it is better than not knowing anything. Analysis of performance can be kept manually as cards but now it is done generally on computers. The data regarding occupancy predication (in case of 3 hotel), history of $\mathrm{F} \& \mathrm{~B}$ sales, consumption patterns and popularity rates over a given period of time will be the basis to plan future food and beverage purchase.

(c) In house manufacture/ Buying Decision is an important area of decisions for the establishment. There are advantages and disadvantages associated with both the options; hence a careful analysis should be made according to the suitability to the operation.

The buying of processed convenience food means paying a higher price and to the value added. If ingredients that go into the product are purchased and the item is produced in house, the cost (at least perceived) is lower, but in-house production means additional labour costs, investment in equipment, more wastage etc.

The convenience product has many advantages like uniform quality, consistent portion control, less wastage, better edible portion, lesser storage and so many other reductions in costs.

The "make" or "buy" decision is not simple. A lot of factors peculiar to the food service operations have to be considered while deciding e.g. labour costs, employee skills, etc. the costs of a wrong decision can be heavy.

(d) Maintain Supplier Diplomacy and Educate Suppliers: Suppliers should be made aware of the establishment's changing needs and requirement so that they can match their services to fulfill new requirements. Potential suppliers should be informed ways in which they can improve their performance.

Cordial relations should be maintained with suppliers to get the best value from them. The establishment may consider purchasing from multiple buyers and earn goodwill, which may prove valuable in emergencies.

(e) Purchase, Receive, Store And Issue Products: In some establishment, the buyer alongwith the duties of selecting suppliers and purchasing also have the responsibility of receiving the products, storing and further issuing to department for final use. But it is not advisable to link the buying and receiving activities since it will create a problem of control. The separation of these two activities reduces to a great extent the change a problem of control. The separation of these two activities reduces to a great extent the chance of theft. 
A Study of Material Management Policies in Chain of Hotel Industry (A Case Study of Taj Hotel)

Apoorva Singh, Arvind Kumar Yadav

(f) Co-operating With Competitors: Co-operating and helping competitors seem to be an unlikely function of a purchasing manager but competing buyers can help each other in mutually beneficial ways. e.g. one can lend products in case of crucial need to the competitor. This can be a reciprocal gesture, which will help both parties.

\section{CoRporate Policies}

Corporate Policies are laid down so as to achieve corporate goals of the organization. In this sense, corporate policies are derived from corporate objectives. The top management expects all departments to work towards the achievement of corporate objective. Corporate policies are broader and from these are derived specific policies consisting of rules which guide various departments. Thus, the objective and policies of materials management are also derived from corporate goals and policies.

If the materials management policy is clearly defined it helps to identify prerogative of material management and avoids confusion, spells out authority and responsibility. It facilitates uniform and consistent action in various activities. Policies help to standardize procedures and systems leading to greater efficiency.

Material management policies should be formulated in the following areas:

9.1 Organization Policies: The acceptance of integrated material management department is a major policy decision. Policies regarding internal, delegation of authority, relations with other department, co-ordination of material management function, identifying training needs etc. need to be established. Development of policy manual is also important.

9.2 Purchasing Policy: Clear Policies should be laid down regarding sources of supplies, quotations, negotiations, quality, quantity, price, personal buying, reciprocity, make or buy decisions etc.

9.3 Inventory Control and Stores: Clear Ruler and procedures must be established for receipt, inspection, storing, issue, physical stocktaking, surplus and obsolete material disposal etc. Clear policies in these areas will help in keeping inventory at desired levels. The policies also ensure proper accounting, minimum lead time, reduce wastage and pilferage etc.

\section{The Material Management Policy in The Hotel Industry}

The purchasing policy governs the food service operations purchasing activity and related. It is not necessary for a purchase policy to be a written document. In many small operations, it may be a verbal set of rules, which all employees are required to follows. Food service operations formulate their purchasing policy as per their need, hence purchasing policies of various establishment are different though the basic elements may be common.

In the study, it was found that large operations have precise written policies. These policies consist of rules, which are direct and clear so that they assist the buyer in taking a good decision. The policies should especially serve as a guide for taking correct and effective decisions in critical situations and in case of any confusion.

Some important areas, which the purchasing policies covers are as follows:

$-380-$ 
10.1 Quantity Limits: The amount of item a purchase manger can buy is restricted to a certain limit. In case, the amount to be brought crosses this limit, prior permission is required compulsorily.

10.2 Price limits: Settlement of price is generally recommended for products purchased in large quantities. If the price rises beyond this limit, a re-evaluation is normally done.

10.3 Gifts from Suppliers: Large organizations have strict rules regarding accepting gifts from suppliers. Acceptance of gifts leads to a psychological pressure to purchase goods from suppliers extending favors.

10.4 Sample Acceptance: Generally, establishments, as a policy matter accept samples only when they are sincerely considering purchasing the product. Few companies prefer purchasing the sample.

10.5 Deciding Suppliers: Most establishments have an approved supplier list. This is very important since it may restrict the buyer's authority and ensure that suppliers are upto required standards. This also takes care of undue pressures the purchasing manager faces due to lack of such an approved list.

10.6 Personal Purchases: Employees are often tempted to take advantage of the establishment's purchasing power. They might want to buy products of their personal use at these wholesale prices. These kinds of purchasing may be offered to employees on special occasions but regular practice can lead to gross mismanagement. Employees may start giving more attention to their personal purchase rather than their work.

10.7 Acceptance of Discounts: The purchase policy should include guidelines on availing discounts. Quantity discounts, cash discounts and promotional discounts are available on purchases.

10.8 Quantity discounts are given on volume purchases. Buyers need to make a balanced decision. Volume purchase may give the advantage of lower price but large volumes of inventory will block cash, need more storage space, cause pilferage, wastage, over-use and spoilage. Buyers need to keep in mind the maximum inventory level while taking the decisions. Cash discounts are extended for making payments on delivery. Cash discounts can be availed considering the cash flow situation in smaller food services operations. Generally, large operation pay invoices by cheques at regular and do not practice cash on delivery.

In the case of promotional discounts, products are supplied at heavily discounted rates allowing the operator considerable savings. Supplied products are featured on the menu or offered as part of service for a specified period of time by the food service operation. It is important that the Food Service Operations wishes to be associated with the product the decision should not be made just to save money. A very successful example of this kind of association is McDonald's and Coca Cola.

10.9 Local Suppliers: Most establishments support local suppliers and in the large run atleast some local purchasing is a beneficial strategy. 
A Study of Material Management Policies in Chain of Hotel Industry (A Case Study of Taj Hotel)

Apoorva Singh, Arvind Kumar Yadav

10.10 Reciprocity: This means purchasing from suppliers who in turn purchase from you. These reciprocal arrangements are sometimes established at the top level as a matter of policy sector undertaking reciprocity policy is adopted.

In case of the hospitality industry reciprocity may be interpreted to mean-if the supplier does something special, he gets reference over other suppliers. In the food business, suppliers' preference can bring very less business as compared to the volume of purchases. And this is basically an uneconomic activity lacking open completion. Hospitality operations generally do not indulge in reciprocal arrangements.

10.11 Written Ethical Guidelines: The materials management policy includes written ethical guidelines by the purchasers. The guidelines pertain to potential ethical dilemmas. This may be a part of buyer's job description.

10.12 Controlling Products: In small hospitality operations, the buyer generally takes the responsibility to items until used. In larger hospitality operations, the responsibilities may be split to exercise control e.g., in a hotel often the receiving clerk is part of the account department. This serves as a control on the purchaser.

10.13 Quality Standards: Establishing quality standards is also a policy decision. The persons with ordering responsibilities has to see that he is adhering to the quality. Buyers in case of hospitality operations do not have final say regarding quality standards.

\section{CASE STUDY}

In this paper we have studied the following case study of Chain Hotels- The Taj Group.

The Taj Group (IHCL): Taj Hotels is a chain of luxury hotels and a subsidiary of the Indian Hotels Company Limited; headquartered at Express Towers, Nariman Point in Mumbai Incorporated by the founder of the Tata Group, Jamshedji Tata, in 1903, the company is a part of the Tata Group, one of India's largest business conglomerates. At present the company operates a total of 100 hotels and hotel-resorts, with 84 across India and 16 in other countries, including Bhutan, Malaysia, Maldives, Nepal, South Africa, Sri Lanka, UAE, UK, USA and Zambia.

Jamshedji Tata, founder of the Tata Group, opened the Taj Mahal Palace, a hotel in Mumbai (formerly called Bombay) overlooking the Arabian Sea, on 16 December 1903. It was the first Taj property and the first Taj hotel. There are several anecdotal stories about why Tata opened the Taj hotel. According to a story, he decided to open the hotel after an incident involving racial discrimination at the Watson's Hotel in Mumbai, where he was refused entry as the hotel permitted only Europeans. Hotels that accepted only European guests were very common across British India then. According to another story, he opened the hotel when one of his friends expressed disgust over the hotels that were present in Bombay at that time. But a more plausible reason was advanced by Lovat Fraser, a close friend of the Tata and one of the early directors of the IHCL group, that the idea had long been in his mind and that he had made a study on the subject. He did not have any desire to own a hotel but he wanted to attract people to India and to improve Bombay. It is said that Jamshedji Tata had travelled to places like London, Paris, Berlin, 
and Düsseldorf to arrange for materials and pieces of art, furniture and other interior decor for his hotel. The Taj group has since then developed and flourished, under the Tata Group.

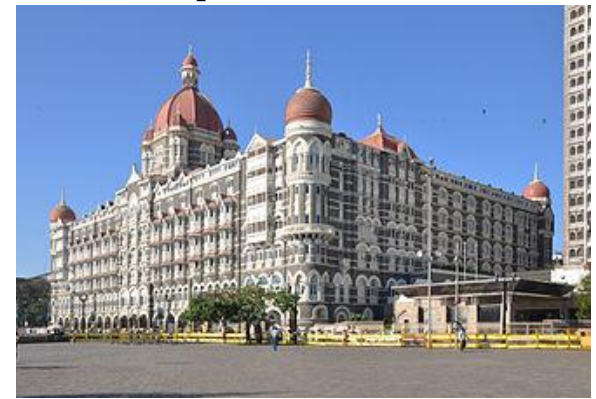

The Taj Mahal Palace in Mumbai is the first hotel of Taj, opened in the year 1903.

In 1974, the group opened India's first international five-star deluxe beach resort, the Fort Aguada Beach Resort in Goa. In 1970s, the Taj Group also began its business in metropolitan hotels, opening the five-star deluxe hotel, Taj Coromandel in Chennai, in 1974, acquiring an equity interest and operating contract for the Taj President (now Vivanta by Taj - President), a business hotel in Mumbai, in 1977, and also opening the Taj Mahal Hotel in Delhi in 1978.

The group has been converting royal palaces in India into luxury hotels since the 1970s. The first palace to be converted into a Taj luxury hotel was the Lake Palace in Udaipur, in 1971. Other examples include the Rambagh Palace in Jaipur, Umaid Bhawan Palace in Jodhpur, Falaknuma Palace in Hyderabad and Nadesar Palace in Varanasi.

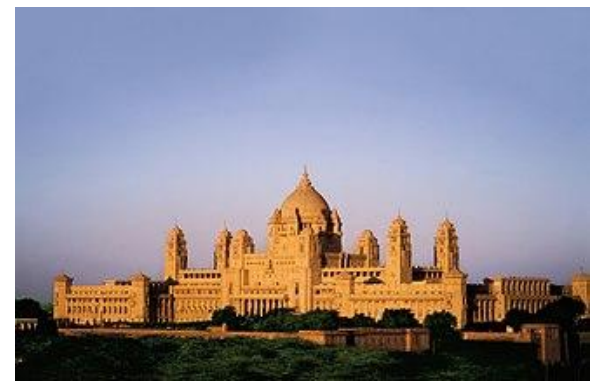

A part of the Umaid Bhawan Palace in Jodhpur is a Taj luxury hotel and it is a member of the Leading Hotels of the World.

In 1980, the Taj group opened its first hotel outside India, the Taj Sheba Hotel in Sana'a, in Yemen and in the late 1980s, acquired interests in the St. James' Court Hotel (now comprising Taj 51 Buckingham Gate Suites and Residences and St. James' Court, A Taj Hotel) in London. In 1984, the Taj group acquired, under a license agreement, each of the Taj West End in Bangalore, Taj Connemara (now Vivanta by Taj - Connemara) in Chennai and Savoy Hotel in Ooty. With the opening of the Taj West End in Bangalore, the Taj Group made its foray into Bangalore. The fivestar deluxe hotel, Taj Bengal in Kolkata, was opened in the year 1989, and with this, the Taj group became the only hotel chain in India with a presence in the six major metropolitan cities of India, namely Mumbai, Delhi, Kolkata, Bangalore, Hyderabad, and Chennai. 
A Study of Material Management Policies in Chain of Hotel Industry (A Case Study of Taj Hotel)

Apoorva Singh, Arvind Kumar Yadav

Concurrently with the expansion of its luxury hotel chain in the major metropolitan cities, the Taj Group also expanded its business hotels division in the major metropolitan and large secondary cities in India. During the 1990s, the Taj Group continued to expand its geographic and market coverage in India. It developed specialized operations (such as wildlife lodges) and consolidated its position in established markets through the upgrading of existing properties and development of new properties. Taj also set up the Taj Kerala Hotels and Resorts Limited in the early 1990s along with the Kerala Tourism Development Corporation.

Ten hotels of the Taj group are members of the Leading Hotels of the World.

The Indian hotels company and its subsidiaries collectively known as Taj Hotel Resort and Palaces is recognized as one of Asia's largest and finest hotel company. It is part of the Tata Group of Companies, India's premier business house.

\section{Material Management Policies Regarding Taj Group of Hotels}

Some important areas of Material Management policies are as under:

(a) Taj Hotels purchase only some items like perishables from local suppliers.

(b) Most items are procured from suppliers approved at the central level from metros.

(c) Taj believes in helping the weaker sections of the society by helping them develop as Taj suppliers.

(d) Taj requires its suppliers to abide by all applicable laws and regulations.

(e) They have a policy of fixed time payment to suppliers generally every 30 days.

(f) Taj has a policy of receiving no gifts from the suppliers. If the supplier tries to pass on gifts it may make the contract void.

(g) They have a policy of accepting samples and returning them after job completion.

(h) Most jobs are done in-house and only essential once are outsourced, though this may vary from one hotel to another.

(i) Taj has a policy to have separate department for purchase and stores.

\section{CONCLUSION}

Material managing policies are important to guide the day-today work of the function and sound policies go a long way in achieving the objectives and goals of the material management department by contributing to the organizational success. Sound policies take care of the routine repetitive decisions and allow the manger to concentrate on exceptional issues. These policies serve as means by which responsibility and authority are delegated and hence it fixes accountability for decisions taken. The effective use of sound policies improves the quality of decisions making. Since on most problems/ issues arising, considered decisions have already been taken. There is less friction or dispute. This helps people in the departments to work as a team. The integrated materials management concept has a number of advantage and it contributes to cost reduction and enhances the productivity of the establishment. There are a number of activities pertaining to the materials manager in the hospitality industry like formulation stores and inventory etc. Taj hotel adopted a very good material management system. This is a chain base unit all over the world so they have adopted a transparent system all over the world. Taj Hotels purchase only some items like perishables from local suppliers. They believe in helping the weaker sections of the society by helping them to develop as Taj suppliers. 
They have a policy of fixed time payment to suppliers generally every 30 days. Another good policy of receiving no gifts from the suppliers. It the supplier tries to pass on gifts it may make the contract void. They have a policy of accepting samples and returning them after job completion. Taj has a policy to have separate department for purchase and stores.

\section{REFERENCES}

\section{Books:}

[1]. Bhatnagar, S.K. (2017), Front Office Management, Frank Brothers and Co. Publishers) Ltd.

[2]. Briggs. R. (2016), Food Purchasing and Preparation, Cassell, London.

[3]. Buttle, F. (2014), Hotel and Food Service Marketing, Cassell, London.

[4]. Cullen. P. (2017), The Food and Beverage Manager, Hospitality Press, Melbourne.

[5]. Datta, A.K. (2016), Materials Management: Procedures, Text and Cases, Second Edition, Prentice Hall of IndiNew Delhi.

[6]. Dittmer, P.R., (2016), Principles of Food, Beverage and Labor Cost Controls, Seventh Edition, John Wiley \& Sons, New York.

[7]. Dobler, D. W., Lee, L. \& Burt, D.N. (2018), Purchasing and Materials Management: Text and Cases, Fourth Edition, Tata McGraw-Hill, New Delhi.

[8]. Feinstein, A.H. \& Stefanelli, J.M. (2016), Purchasing: Selection and Procurement for the Hospitality Industry, Fifth Edition, John Wiley \& Sons, New York.

[9]. Gopalkrishnan, P. \& Sundaresan, M. (2017), Materials Management: An Integrated Approach, Prentice Hall, New Delhi.

[10]. Gray, W.S. \& Liguosi S.C. (2014), Hotel and Motel Management and Operations. Second Edition, Prentice Hall, New Jersey.

[11]. Gray, W.S. (2016), Hospitality Accounting, Prentice Hall, New Jersey.

[12]. Heinritz, S.F., Farrell, P.V. and Smith, C.L. (2008), Purchasing: Principles and Applications, Prentice Hall, New Jersey.

[13]. Kotler, P , Bowen, J. \& Makens, J. (2012), Marketing for Hospitality and Tourism Third Edition, Dorling Kindersley, India.

[14]. Mamoria, C.B. \& Mamoria. S. (2013), Business Planning and Policy, Himalaya Publishing House, Bombay.

[15]. Nair, N.K. (2017), Purchasing and Materials Management, Vikas Publishing House, New Delhi.

[16]. Nargundkar. R. (2019), Marketing Research: Text and Cases, Second Edition, Tata McGraw Hill, New Delhi.

[17]. Negi, J. (2018), Food and Beverage Management and Cost Control, Kanishka Publishers, New Delhi.

[18]. Sahay, B.S. (2013), Supply Chain Management in the Twenty First Century, McMillan, New Delhi.

\section{Magazines, Newspapers, Journals, Websites}

[1]. Amar Ujala

[2]. Dainik Jagran

[3]. Hindustan Times 
A Study of Material Management Policies in Chain of Hotel Industry (A Case Study of Taj Hotel) Apoorva Singh, Arvind Kumar Yadav

[4]. Hospitality industry meet opens on Aug- 23, available from (URL:http://ww.hindu.com/2010/08/19/stories/2010081955201200.htm).

[5]. Hospitality industry, available from (URL:http://en.wikipedia. org/wikhospitality_industry).

[6]. Hospitality industry, available from (URL:http://www.naukrihub.com/ India hospitality).

[7]. Hospitality, Tourism poisedfor high growth: Army Chief, available from (URL:http://www.hindu.com/thehindu/holnus/ 002200708171624.htm).

[8]. Hotel Industry in India, 21 July 09, available from (URL:http://www. ilovenida.com/economy-of-India/hotel-industry. html).

[9]. http:www.tajhotels.com/AboutTaj/CompanyInformation/default.htm.

[10]. Indian Hotel Industry, available from (URL:http://www.researchandmarkets.com/reports/c66471).

[11]. Times of India 